\begin{tabular}{|c|c|c|c|c|}
\hline $\begin{array}{c}\text { Focus: } \\
\text { Jurnal Pekerjaan Sosial }\end{array}$ & ISSN: 2620-3367 & Vol. 2 No: 1 & Hal: $67-83$ & Juli 2019 \\
\hline
\end{tabular}

\title{
PENERAPAN COGNIIVE RESTRUCTRING FORM(CRF) DAN DEEP BREATHING PADA REMAJ A DENGAN LOW SELF ESTEEM
}

\author{
Nabila Nur Arsyila1, Meilanny Budiarti Santoso² \\ Universitas Padjadjaran \\ ${ }^{1}$ nurarsyilanabila@gmail.com, 2meilannybudiarti13@gmail.com
}

\begin{abstract}
ABSTRAK
Remaja merupakan suatu masa transisi perkembangan antara masa kanak-kanak dan dewasa. Dan pada tahap ini remaja harus menjalankan tugasnya, Apabila tugas pekembangan sosial ini dapat dilakukan dengan baik, remaja tidak akan mengalami kesulitan dalam kehidupan sosialnya serta akan membawa kebahagiaan dan kesuksesan dalam menuntaskan tugas perkembangan untuk fase-fase berikutnya. Sebaliknya, jika remaja gagal menjalankan tugas-tugas perkembangannya akan membawa akibat negatif dalam kehidupan sosial fasefase berikutnya, menyebabkan ketidakbahagiaan pada remaja yang bersangkutan, menimbulkan penolakan masyarakat, dan kesulitan-kesulitan dalam menuntaskan tugas-tugas perkembangan berikutnya. Tetapi pada masa ini mereka sangat rentan untuk di pengaruhi oeh lingkungan sekitarnya sehingga seringkali mereka terjerumus pada perilaku negatif. sulit untuk Maka dari itu pada tahap ini remaja harus di arahkan pada kegiatan dan pikiran pikiran yang positif. Dalam kasus yang akan di tangani dalam praktikum ini merupakan remaja yang berhadapan dengan hukum tetapi memiliki kepercayaan diri yang kurang, maka dari itu klien di berikan treatment Cognitive Restructring Form (CRF) dan. Deep Breathing.
\end{abstract}

Kata Kunci: Remaja, pengandilan emosi, kepercayaan diri, CRF, deep breathing

\section{ABSTRACK}

Teenage is a transitional period of development between childhood and adulthood. And at this stage adolescents must carry out their duties, If the task of social development can be done well, adolescents will not experience difficulties in their social life and will bring happiness and success in completing developmental tasks for the next phases. Conversely, if adolescents fail to carry out the tasks of development will bring negative consequences in the social life of the next phases, causing unhappiness in the teenager concerned, causing public rejection, and difficulties in completing the tasks of the next development. But at this time they are very vulnerable to be influenced by the surrounding environment so often they fall into negative behavior. difficult for this reason, at this stage teenagers must be directed at activities and positive thoughts. In the case to be handled in this practicum there are teenagers who are dealing with the law but have less selfconfidence, therefore the client is given a Cognitive Restructring Form (CRF) and treatment. Deep Breathing.

Keywords: Adolescence, emotional suppression, confidence, CRF, deep breathing 


\begin{tabular}{|c|c|c|c|c|}
\hline $\begin{array}{c}\text { Focus: } \\
\text { Jurnal Pekerjaan Sosial }\end{array}$ & ISSN: 2620-3367 & Vol. 2 No: 1 & Hal: $67-83$ & Juli 2019 \\
\hline
\end{tabular}

\section{Pendahuluan}

Berbagai faktor bagi anak untuk melakukan kenakalan dan kegiatan kriminal yang dapat membuat mereka terpaksa berhadapan dengan hukum dan sistem peradilan. Anak yang melakukan tindak pidana ini bisa disebut pula dengan anak yang berhadapan dengan hukum. Berdasarkan Pasal 1 ayat (2) Undang-Undang Nomor 11tahun 2012 tentang Sistem Peradilan Pidana Anak yang dimaksud dengan anak yang berhadapan dengan hukum adalah anak yang berkonflik dengan hukum, anak yang menjadi korban tindak pidana, dansaksitindak pidana. Hal ini merupakan arus balik yang tidak diperhitungkan dari proses dan perkembangan pembangunan bangsa-bangsa yang mempunyai cita-cita tinggi dan masa depan cemerlang guna menyongsong dan menggantikan pemimpin-pemimpin bangsa Indonesia.

Berdasarkan Undang-Undang No. 12 Tahun 1995 tentang Pemasyarakatan, pembinaan bagi narapidana anak dilakukan sesuaidengan konsep pemasyarakatan dengan tujuan untuk memberikan bimbingankepada anak didik Lembaga Pembinaan Khusus Anak agar memiliki kesiapanyang baik untuk kembali ke dalam kehidupan bermasyarakat sebagai seorangwarga negara yang bertanggungjawab.

Lembaga Pembinaan Khusus Anak Kelas II Bandung merupakan salahsatu Lembaga Pemasyarakatan pusat bagi anak berhadapan dengan hukum dij awa Barat yang mulai beroperasi pada tahun 2013 dalam menangani 7 (tujuh)kasus dengan jumlah anak didik sebanyak 146 orang dengan tindak pidanadidominasi oleh kasus pencurian, pembunuhan, perlindungan anak, dan narkoba.

Mayoritas anak didik Lembaga Pembinaan Khusus Anak berada padarentang usia remaja, yaitu 16-18 tahun. Berdasarkan Undang-Undang No. 11Tahun 2012, anak didik yang menempati Lembaga Pembinaan Khusus Anaksudah dibatasi dengan usia maksimal 17 tahun, sedangkan bila lebih dari 17tahun, anak sudah dapat dimasukkan ke dalam Lembaga PemasyarakatanDewasa. Pada masa perkembangan dirinya sebagai seorang remaja, anak didikLembaga Pembinaan Khusus Anak akan mengalami perkembangan dalamkematangan mental, emosional, sosial, dan fisik (Hurlock, 1991).

Perkembangan diri anak untuk melewati masa remaja akan dipengaruhi olehinteraksi sosial dirinya dengan lingkungan fisik dan sosial di sekitarnya. Dalamhal ini, anak akan menghadapi situasi lingkungan fisik dan sosial yang baru diLembaga Pembinaan Khusus Anak dan kehidupan bermasyarakat dengansituasi dan kondisi yang berbeda terhadap dirinya selepas keluar dari LembagaPembinaan Khusus Anak. Bila anak tidak dapat menangani kesenjangan antarakebutuhan dan kenyataan yang ada, maka kemungkinan akan berdampakterhadap timbulnya perilaku negatif atau perilaku menyimpang.

\section{Masa Remaja}

Tidak mudahuntuk mendefinisikan remaja secara tepat, karena banyak sekali sudut pandang yang dapat digunakan dalam mendefinisikan remaja. Kata "remaja" berasal dari bahasa Latin adolesceneyang berarti to grow atau to grow maturity (Golinko, 1984, Rice, 1990 dalam (Jahja, 2011) 


\begin{tabular}{|c|c|c|c|c|}
\hline $\begin{array}{c}\text { Focus: } \\
\text { Jurnal Pekerjaan Sosial }\end{array}$ & ISSN: 2620-3367 & Vol. 2 No: 1 & Hal: $67-83$ & Juli 2019 \\
\hline
\end{tabular}

$\begin{array}{rrrr}\text { Banyak } & \text { tokoh yang memberikan } \\ \text { definisiremaja, } & \text { seperti } & \text { DeBrun } & (1990) \\ \text { mendefinisikan } & \text { remaja } & \text { sebagai } & \text { periode }\end{array}$
pertumbuhan antara masa kanak-kanak dan dewasa.Papalia dan Olds(2001) tidak memberikan pengertian remaja secara eksplisit melainkan secara implisit melalui pengertian masa remaja (adolescence). Menurut Papalia dan Olds (2001), masa remaja adalah masa transisi perkembangan antara masa kanak-kanak dan dewasa yang pada umumnya dimulai pada usia 12 atau 13 tahun dan berakhir pada usia akhir belasan tahun atau awal dua puluh tahun. Sedangkan Anna Freud (dalamHurlock, 1990), berpendapat bahwa pada masa remaja terjadi proses perkembangan meliputi perubahan-perubahan yang berhubungan dengan perkembangan psikoseksual, dan juga terjadi perubahan dalam hubungandengan orangtua dan cita-cita mereka, di mana pembentukan cita-cita merupakan proses pembentukan orientasi masa depan.

Salah satu periode dalam rentang kehidupan ialah fase remaja. Masa ini merupakan segmen kehidupan yang penting dalam siklus perkembangan individu, dan merupakan masa transisi yang dapat diarahkan kepada perkembangan masa dewasa yang sehat. Untuk dapat melakukan sosialisasi dengan baik, remaja harus menjalankan tugas-tugas perkembangan pada usinya dengan baik. Apabila tugas pekembangan sosial ini dapat dilakukan dengan baik, remaja tidak akan mengalami kesulitan dalam kehidupan sosialnya serta akan membawa kebahagiaan dan kesuksesan dalam menuntaskan tugas perkembangan untuk fase-fase berikutnya. Sebaliknya, manakala remaja gagal menjalankan tugas-tugas perkembangannya akan membawa akibat negatif dalam kehidupan sosial fase-fase berikutnya. Hal ini menyebabkan ketidakbahagiaan pada diri remaja yang bersangkutan, menimbulkan penolakan masyarakat, dan kesulitan-kesulitan dalam menuntaskan tugas-tugas perkembangan berikutnya.

Hurlock (1981) menyebut tugas - tugas perkembangan ini sebagai social expectations yang artinya setiap kelompok budaya mengharapkan anggotanya menguasai keterampilan tertentu yang penting dan memperoleh pola perilaku yang disetujui oleh berbagai usia sepanjang rentang kehidupan. Faktor sumber munculnya tugas tugas perkembangan :

1.Adanya kematangan fisik tertentu pada fase perkembangan tertentu

2.Tuntutan masyarakat secara kultural : membaca, menulis, berhitung, dan organisasi

3.Tuntutan dari dorongan dan cita - cita individu sendiri (psikologis) yang sedang berkembang itu sendiri : memilih teman dan pekerjaan

4.Tuntutan norma agama

Masa remaja merupakan usia peralihan dari masa anak-anak ke masa dewasa yang memiliki berbagai maslah, baik bagi remaja sendiri maupun bagi masyarakat. Bagi diri remaja sendiri, penghayatan baru itu memerlukan cara penyesuaian baru yang kadang-kadang gagal atau kurang berhasil dilakukan. Hal ini disebabkan oleh kemampuan remaja yang belum memadai, status dewasanya yang belum mantap. Untuk mengatasinya remaja memerlukan pengertian dan uluran tangan orang dewasa secara langsung maupun tidak langsung. Walaupun remaja sedang berusaha mampu berdiri sendiri, namun karena kurangnya pengalaman mereka memerlukan 


\begin{tabular}{|c|c|c|c|c|}
\hline $\begin{array}{c}\text { Focus: } \\
\text { Jurnal Pekerjaan Sosial }\end{array}$ & ISSN: 2620-3367 & Vol. 2 No: 1 & Hal: $67-83$ & Juli 2019 \\
\hline
\end{tabular}

bimbingan yang tepat sesuai dengan kebutuhankebutuhan baru yang dihadapinya.

Berbagai bentuk dan cara penyesuaian yang negatif akan nampak dalam interaksi sosial remaja dan hal ini mempengaruhi kehidupan sosial remaja secara luas. Situasi tersebut akan menimbulkan berbagai maalah seperti kenakalan remaja, pelanggaran susila, pelanggaran lalu lintas, pengangguran, drop out, tawuran dan lain sebagainya.

Cara penyesuaian diri remaja yang negatif tersebut jika tidak di tangani dengan tepat, akan terbawa hingga usia dewasa. Hal ini akan membuat remaja kurang berpartisipsi dalam kehidupan bermasyarakat. Mengingat berbagai tugas perkembangan remaja sangat kompleks dan relatif berat untuk dijalani oleh remaja, maka untuk dapat melaksanakan tugas-tugas perkembangan tersebut dengan baik, remaja membutuhkan bimbingan dan pengarahan agar dapat menentukan langkah yang tepat dan sesuai dengan kondisinya.

Selain berbagai macam tugas perkembangan, remaja pun memiliki berbagai macam kebutuhan yang tentu saja menuntut pemenuhan secepat mungkin, sesuai gejolak darah mudayang ada pada diri remaja. Berbagai kebutuhan pada diri remaja tersebut, menurut Edward (1953): (1) kebutuhan untuk mencapai sesuatu, (2) kebutuhan akan rasa superior, ingin menonjol, ingin terkenal, (3) kebutuhan untuk mendapatkan penghargaan, (4) kebutuhan akan keteraturan, (5) kebutuhan akan adanya kebebasan untuk menentukan sikap sesuai dengan kehendaknya, (6) kebutuhan untuk menciptakan hubungan persahabatan, (7) adanya keinginan ikut berempati, (8) kebutuhan mencari bantuan dan simpati, (9) keinginan menguasai tetapi tidak ingin dikuasai, (10) menganggap diri sendiri rendah, (11) adanya kesediaan untuk membantu orang lain, (12) kebutuhan adanya variasi dalam kehidupan, (13) adanya keuletan dalam melaksanakan tugas, (14) kebutuhan untuk betgaul dengan lawan jenis, dan (15) adanya sikap suka mengkritik orang lain.

Intensitas munculnya keinginan untuk pemenuhan berbagai kebutuhan di atas tidak semua sama antara individu yang satu dengan yang lain, karena kondisi pribadi masing-masing remaja yang berbeda, situasi lingkungan yang berlainan, dan ada individu yang ingin segera kebutuhannya terpenuhi, namun kenyataannya banyak yang tidak terpenuhi. Dari uraian ini nampak bahwa tugas perkembangan dan kebutuhan merupakan sesuatu yang muncul pada periode tertentu dalam rentang kehidupan remaja.

Apabila tugas perkembangan dan kebutuhan dapat terpenuhi, maka membawa kebahagiaan dan kesuksesan dalam menjalankan dan menuntaskan berbagai tugas perkembangan di tahapan berikutnya. Sebaliknya apabila gagal, maka akan menyebabkan ketidakbahagiaan pada remaja yang bersangkutan, menimbulkan penolakan oleh masyarakat, dan menimbulkan kesulitan-kesulitan dalam menuntaskan berbagai macam tugas perkembangan pada peridodeperiode berikutnya.

Masa remaja merupakan salah satu masa yang harus dilewati dalam setiap perkembangan individu untuk menjadi dewasa. Masa perkembangan remaja adalah periode dalam perkembangan individu untuk dapat mencapai 


\begin{tabular}{|c|c|c|c|c|}
\hline $\begin{array}{c}\text { Focus: } \\
\text { Jurnal Pekerjaan Sosial }\end{array}$ & ISSN: 2620-3367 & Vol. 2 No: 1 & Hal: $67-83$ & Juli 2019 \\
\hline
\end{tabular}

kematangan mental, emosional, sosial, fisik dan pola peralihan dari masa kanak-kanak menuju dewasa (Hurlock, 1991; Malahayati, 2010), sehingga menimbulkan karakteristik yang berbeda antara satu remaja dengan remaja lain. Perubahan yang terjadi pada masa remaja seperti pertumbuhan secara cepat baik fisik, psikis ( stress, anxiety, depresi) dan sosial menimbulkan banyak persoalan dan tantangan. Salah satu permasalahan yang banyak dirasakan dan dialami oleh remaja pada dasarnya disebabkan oleh kurang percaya diri (Rizkiyah, 2005).

\section{Kepercayaan diri}

Kepercayaan diri merupakan salah satu aspek kepribadian yang penting dalam masa perkembangan remaja. Percaya diri adalah suatu perasaan dan keyakinan terhadap kemampuan yang dimiliki untuk dapat meraih kesuksesan dengan berpijak pada usahanya sendiri dan mengembangkan penilaian yang positif bagi dirinya sendiri maupun lingkungannya sehingga, seseorang dapat tampil dengan penuh keyakinan dan mampu menghadapi segala sesuatu dengan tenang. Kepercayaan diri berperan dalam memberikan sumbangan yang bermakna dalam proses kehidupan seseorang. Kepercayaan diri merupakan salah satu modal utama kesuksesan untuk menjalani hidup dengan penuh optimisme dan kunci kehidupan berhasil dan bahagia.

Kepercayaan diri pada remaja tampak pada sikap yang menerima diri sebagaimana adanya. Penerimaan diri merupakan sikap yang mencerminkan rasa senang sehubungan dengan kenyataan diri sendiri. Sikap tersebut merupakan perwujudan dari kepuasan terhadap kualitas kemampuan diri yang nyata. Remaja yang puas pada kualitas dirinya akan cenderung merasa aman, tidak kecewa dan tahu apa yang dibutuhkannya, sehingga dapat mandiri dan tidak bergantung pada orang lain dalam memutuskan segala sesuatu secara objektif. Remaja yang percaya diri juga cenderung mempunyai gambaran dan konsep diri yang positif. Hurlock (1991) menyatakan bahwa reaksi positif seseorang terhadap penampilan dirinya sendiri akan menimbulkan rasa puas yang akan mempengaruhi perkembangan mentalnya. Disisi lain, remaja yang kurang percaya diri akan menunjukkan perilaku seperti, tidak bisa berbuat banyak, selalu ragu dalam menjalan tugas, tidak berani berbicara jika tidak mendapatkan dukungan, menutup diri, cenderung sedapat mungkin menghindari situasi komunikasi, menarik diri dari lingkungan, sedikit melibatkan diri dalam kegiatan atau kelompok, menjadi agresif, bersikap bertahan dan membalas dendam perlakuan yang dianggap tidak adi.

Menurut Mastuti \& Aswi (2008) individu yang tidak percaya diri biasanya disebabkan oleh individu tersebut tidak mendidik sendiri dan hanya menunggu orang melakukan sesuatu kepada dirinya. Semakin individu kehilangan suatu kepercayaan diri, maka akan semakin sulit untuk memutuskan yang terbaik apa yang harus dilakukan kepada dirinya, dalam keadaan yang seperti ini remaja cenderung akan kehilangan motivasi dalam melakukan banyak hal terutama belajar. Beberapa hasil penelitian mengungkapkan bahwa tingkat kepercayaan diri remaja berada pada kategori sedang hanya sebagian kecil dari remaja yang memiliki rasa percaya diri yang tinggi.

Kepercayaan diri adalah salahsatu aspek kepribadian yang penting pada seseorang. Kepercayaan diri merupakan atribut yang sangat 


\begin{tabular}{|c|c|c|c|c|}
\hline $\begin{array}{c}\text { Focus: } \\
\text { Jurnal Pekerjaan Sosial }\end{array}$ & ISSN: 2620-3367 & Vol. 2 No: 1 & Hal: $67-83$ & Juli 2019 \\
\hline
\end{tabular}

berharga pada diri seseorang dalam kehidupan bermasyarakat,tanpa adanya kepercayaan diri akan menimbulkan banyak masalah pada diri seseorang. Hal tersebut dikarenakan dengan kepercayaan diri, seseorang mampu untuk mengaktualisasikan segala potensinya. Kepercayaan diri merupakan sesuatu yang urgenuntuk dimiliki setiap individu. Kepercayaan diri diperluhkan baik oleh seorang anak maupun orang tua, secara individual maupun kelompok. Menurut Willis (1985) kepercayaan diri adalah keyakinan bahwa seseorang mampu menanggulangi suatu masalah dengan situasi terbaik dan dapat memberikan sesuatu yang menyenangkan bagi orang lain. Loekmono mengemukakan bahwa kepercayaan diri tidak terbentuk dengan sendirinyamelainkan berkaitan dengan kepribadian seseorang. Kepercayaan diri dipengaruhi oleh faktor-faktor yang berasal diri dalam individu sendiri. Norma dan pengalaman keluarga, tradisi kebiasaan dan lingkungansosial atau kelompok dimana keluarga itu berasal.

Kepercayaan diri merupakan percayaan kepada diri sendiri yang ditentukan oleh pengalaman-pengalaman yang dilalui sejak kecil. Orang yang percaya pada diri sendiri dapat mengatais segala faktor-faktor dan situasi, bahkan mungkin frustasi, bahkan mungkin frustasi ringan tidak akan terasa sama sekali. Tapi sebaliknya orang yang kurang percaya diri akan sangat peka terhadap bermacam-macam situasi yang menekan.

Kepercayaan diri merupakan suatu keyakinan yang dimiliki seseorang bahwa dirinya mampu berperilaku seperti yang dibutuhkan untuk memperoleh hasil seperti yang diharapkan (Bandura, 1977). Lauster (1978), mengungkapkan ciri-ciri orang yang percaya diri adalah: mandiri, tidak mementingkan diri sendiri, cukup toleran, ambisius, optimis, tidak pemalu, yakin dengan pendapatnya sendiri dan tidak berlebihan.

Meskipun kepercayaan diri diidentikan dengan kemandirian, orang yang kepercayaandirinya tinggi umumnya lebih mudah terlibat secara pribadi dengan orang lain dan lebih berhasil dalam hubungan interpersonal (Goodstadt \& Kipnir, dalam Bunker dkk, 1983). Menurut Lauster (1978), rasa percaya diri bukan merupakan sifat yang diturunkan (bawaan) melainkan diperoleh dari pengalaman hidup, serta dapat diajarkan dan ditanamkan melalui pendidikan, sehingga upaya-upaya tertentu dapat dilakukan guna membentuk dan meningkatkan rasa percaya diri. Dengan demikian kepercayaaan diri terbentuk dan berkembang melalui proses belajar di dalam interaksi seseorang dengan lingkungannya.

Rendahnya rasa percaya diri dapat menyebabkan rasa tidak nyaman secara emosional yang bersifat sementara tetapi dapat menimbulkan banyak masalah. Rendahnya rasa percaya diri bisa menyebabkan depresi, bunuh diri, anoreksia nervosa, delikuensi, dan masalah penyesuaian diri lainnya. Tingkat percaya diri yang rendah berhubungan dengan proses belajar seperti prestasi rendah atau kehidupan keluarga yang sulit, atau dengan kejadian-kejadian yang membuat tertekan, masalah yang muncul dapat menjadi lebih meningkat (Santrock, 2003).

\section{Cognitive Restructuring}

Cognitive restructuring lahir dari terapi kognitif dalam konseling yang menekankan kepada kekuatan pikiran yang positif dan logis hadir menjadi salah satu solusi atas permasalahan seseorang. Cognitive restructuring lazim digunakan 


\begin{tabular}{|c|c|c|c|c|}
\hline $\begin{array}{c}\text { Focus: } \\
\text { Jurnal Pekerjaan Sosial }\end{array}$ & ISSN: $2620-3367$ & Vol. 2 No: 1 & Hal: $67-83$ & Juli 2019 \\
\hline
\end{tabular}

dengan individu-individu yang pikirannya terpolarisasi, menunjukkan ketakutan dan kecemasan dalam situasi-situasi tertentu, atau bereaksi berlebihan terhadap masalah-masalah kehidupan biasa dengan menggunakan langkahlangkah ektrem sebagai solusi. Cognitive Resturucturing Formiuga merupakan salah satu dari metode dalam pekerja sosial untuk mengatasi masalah yang menyangkut dengan kondisi cognitive seseorang. Terdapat beberapa tahapan untuk melakukan Cognitive Resturucturing Form, yaitu:

1) Yang paling penting adalah memberikan penjelasan terlebih dahulu maksud dan tujuan digunakannya kolom cognitive restructuring kepada klien. Sehingga klien bisa memahami maksud dan tujuan dari form tersebut lalu bisa sehingga menimbulkan emosi pada klien.

3) Meminta klien untuk menyebutkan self talk negative apa yang dipikirkan dari suatu kejadian.

4) Berdiskusi dengan kilen apakah jawaban yang ia keluarkan adalah benar dan memang sesuatu yang harus di pikikan. Jika kita mendapatkan jawaban yang tidak seharusnya dari kilen kita harus mengarahkan kepada pikran-pikiran positif.

5) Setelah kilen mengerti bagaimana cara mengisi tabel Cognitive Resturucturing Formmaka klien ditugaskan untuk mengisi tabel tersebut selama 2 minggu.

Tabel 1

Cognitive Restructing Form 6 kolom

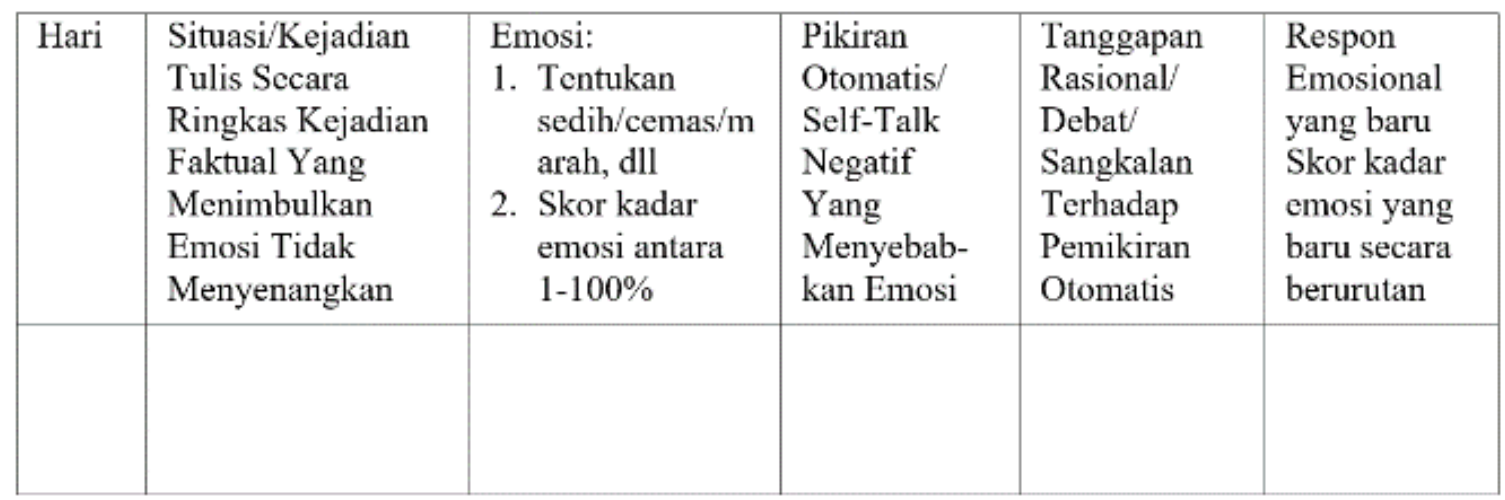

Sumber: Praktikum Pekerjaan Sosial dengan Individu dan Pengembangan Diri, 2019

mengisinya dengan benar.

2) Dimulai dengan menuliskan contohdan memberi gambaran pada klien, dan situasi apa yang pernah dialami
4. DeepBreathing

Deep breathingmerupakan teknik pernapasan yang mudah untuk dilakukan sebagai salah satu teknik yang digunakan oleh pekerja 


\begin{tabular}{|c|c|c|c|c|}
\hline $\begin{array}{c}\text { Focus: } \\
\text { Jurnal Pekerjaan Sosial }\end{array}$ & ISSN: $2620-3367$ & Vol. 2 No: 1 & Hal: $67-83$ & Juli 2019 \\
\hline
\end{tabular}

sosial untuk mengatasi kecemasan dan juga stress yang dialami, baik oleh klien ataupun digunakan oleh pekerja sosial sendiri ketika mengalami situasi kecemasan ataupun stress. Teknik pernapasan deep breathingsangat mudah untuk dilakukan, dan bisa digabungkan dengan teknik relaksasi lainnya. Berikut ini adalah langkah-langkah untuk melakukan teknik deep breathing, yaitu:

1) Posisikan tubuh klien secara nyaman, disarankan untuk duduk tegak dan tidak terganggu atau terdistraksi.

2) Instruksikan klien agar memejamkan matasecara perlahan dan usahakan teknik ini dilakukan di ruangan yang sunyi dan tidak ramai

3) Letakkan satu tangan klien pada bagian dada, dan rasakan detak jantung klien. Agar bisa merasakan perbedaan sebelum dan sesudah melakukan teknik ini.

4) Tarik napas melalui hidung dengan kuat, hingga klien dapat merasakan semua nafas yang dihirupnya telah memenuhi bagian perut klien.

5) Kemudian instruksikan klienuntuk melepaskan atau menghembuskan nafas melalui mulut secara perlahan, rasakan ketika klien menghembuskan nafas. Usahakan klien tetap fokus pada pernapasan.

6) Lakukan pernapasan ini beberapa kali, sesuai dengan kebutuhan.

Teknik deep breatihingdiberikan kepada klien agar memperoleh ketenangan pikiran dan jiwa. Keberhasilanteknik ini ditentukan oleh tingkat rileks yang dirasakan oleh klien.

\section{Metode}

Metode yang digunakan adalah metodologi andragogi yang mensyaratkan klien diposisikan sebagai orang dewasa dan didorong untuk berperan aktif dalam setiap tahapan kegiatan. Baik melalui teknikbrainstrormingguna mengungkap berbagai permasalahan yang dihadapi remaja dan juga teknik sharing pengalaman diantara sesama peserta pelatihan dan juga fasilitator pelatihan. Hal ini bertujuan agar peserta pelatihan dapat melihat segala sesuatu yang terkait dengan permasalahan yang sedang dihadapi dari sudut pandang yang berbeda, hingga menemukan sudut pandang baru yang lebih positif dan dapat mengubah cara berpikir dan berperilaku mereka di kemudian hari.

\section{Hasil dan Pembahasan}

\section{Hasil Assesment}

Assessment merupakan tahapan sebelum dilakukannya tahap intervensi. Assessment dilakukan dengan cara menggali informasi sebanyak banyaknya mengenai keberadaan klien, yaitu data/informasi terkait keluarga, kekurangan\&kelebihan, pertemanan yang dimiliki klien, dan berbagai data lainnya terkait diri klien. Assessment dilakukan untuk menyusun rencana intervensi apa yang akan diberikan oleh praktikan kepada klien. Apakah teknik pendampinganyang ditujukan untuk mengembangkan potensi yang dimiliki oleh klien ataukah melakukan proses pertolongan untuk mencari solusi dengan bekerja bersama klien dalam mengatasi permasalahan yang dihadapinya. 


\begin{tabular}{|c|c|c|c|c|}
\hline $\begin{array}{c}\text { Focus: } \\
\text { Jurnal Pekerjaan Sosial }\end{array}$ & ISSN: 2620-3367 & Vol. 2 No: 1 & Hal: $67-83$ & Juli 2019 \\
\hline
\end{tabular}

Pada awal pertemuan antara praktikan dengan klien, masing-masing kami saling memperkenalkan diri dan praktikan menjelaskan maksud serta tujuan dari dilaksanakannya kegiatan praktikum. Setelah diberikan penjelasan, klien pun dapat mengerti maksud dan tujuan dilakukannya kegiatan praktikum ini. Dalam kesempatan ini, praktikan menanyakan apakah klien bersedia untuk terlibat dalam kegiatan praktikum ini dan klien pun terbuka dan lebih suka menyendiri karena kuang percaya diri jika berinteraksi dengan orang lain, terutama orang yang baru ia kenal.

Dalam tahap assessmentini, praktikan mengidentifikasi berbagai macam kelebihan dan kekurangan klien yang, yaitu untuk mengetahui masalah dan potensi yang dimiliki oleh klien. Hal tersebut tertuang dalam tabel 2 berikut ini:

Tabel 2

Kelebihan dan Kekurangan Klien

\begin{tabular}{|c|c|c|c|c|}
\hline Nama & kelebihan & kekurangan & Masalah & $\begin{array}{l}\text { Aspek Pribadi yang } \\
\text { ingin dikembangkan }\end{array}$ \\
\hline $\mathrm{A}$ & $\begin{array}{l}\text { 1. Bermain } \\
\text { Gitar dan } \\
\text { Bernyanyi } \\
\text { 2. Olahraga }\end{array}$ & $\begin{array}{l}\text { 1. } \begin{array}{l}\text { Sulit } \\
\text { beradaptasi } \\
\text { dengan orang } \\
\text { baru }\end{array} \\
\text { 2. Bingung cara } \\
\text { berkomunikasi } \\
\text { yang baik dan } \\
\text { benar terutama } \\
\text { jika berbicara } \\
\text { dengan lawan } \\
\text { jenis akan } \\
\text { gugup } \\
\text { 3. Gampang emosi } \\
\text { 4. Sulit untuk } \\
\text { bilang tidak } \\
\text { kepada teman }\end{array}$ & $\begin{array}{l}\text { 1. Jika emosi bisa } \\
\text { sampai terpikir } \\
\text { untuk melakukan } \\
\text { hal yang } \\
\text { seharusnya tidak } \\
\text { dilakukan } \\
\text { 2. Tidak percaya } \\
\text { diri jika } \\
\text { berkomunikasi } \\
\text { atau bertemu } \\
\text { orang lain. }\end{array}$ & 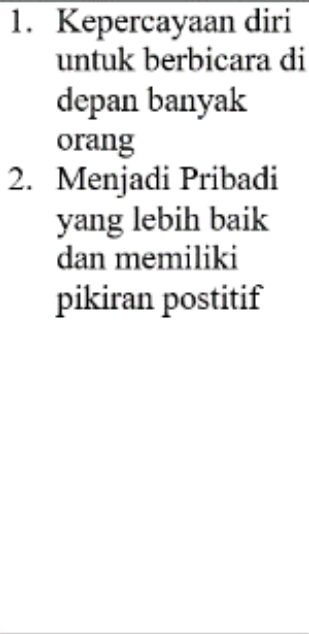 \\
\hline
\end{tabular}

Sumber: Praktikum Pekerjaan Sosial dengan Individu dan Pengembangan Diri, 2019

menyatakan bersedia untuk terlibat.

Setelah memperkenalkan diri, bahwa klien adalah seorang remaja laki-laki bernama $\mathrm{A}$ berusia 16 tahun, klien mengungkapkan pada praktikan bahwa ia memiliki kelebihandan kekurangan pada dirinya. Kelebihan klien adalah sangat suka olahraga, bermain gitar dan bernyanyi. Banyak kegiatan olahraga yang diikuti oleh klien dan sering lakukannya selama tinggal di LPKA yaitu bulutangkis, volly, senam dan futsal. Klien mengungkapkan bahwa kekurangan klien adalah bahwa sebenarnya ia orang yang tidak terlalu
Berdasarkan tabel 2 tersebut, tampak bahwa klien memiliki masalah kepercayaan diri dan memiliki pikiran-pikiran negatif dalam dirinya. Setelah mengetahui masalah yang klien hadapi, kemudian praktikan mencaritahu mengenai keluarganya. Keluarga adalah lingkungan terdekat dan pertama yang membentuk karakteristik seseorang. Berdasarkan informasi yang diungkapkan oleh klien mengenai keluarganya, hal tersebut tertuang dalam geogram berikut ini: 


\begin{tabular}{|c|c|c|c|c|}
\hline $\begin{array}{c}\text { Focus: } \\
\text { Jurnal Pekerjaan Sosial }\end{array}$ & ISSN: 2620-3367 & Vol. 2 No: 1 & Hal: $67-83$ & Juli 2019 \\
\hline
\end{tabular}

Diagram 1

Genogram Klien

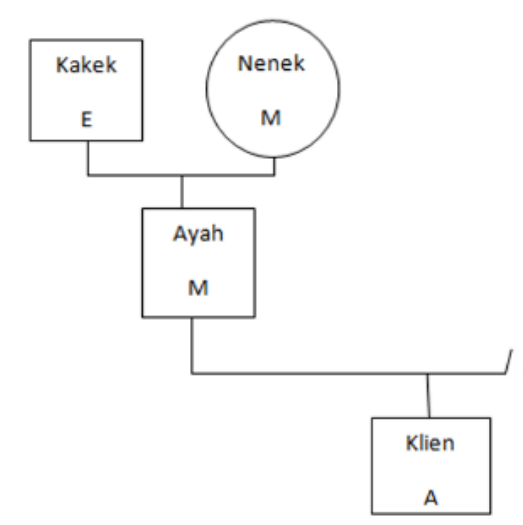

Berdasarkan genogram yang diungkapkan oleh klien, tampak bahwa klien adalah anak pertama dari Bapak M yang berumur 43 tahun dan Ibu J yang berumur 31 tahun, kedua orang tua klien sudah bercerai sejak tahun 2016. Klien mempunyai dua orang adik, yang pertama adalah $\mathrm{F}$ berumur 14 tahun dan $\mathrm{A}$ berumur 10 tahun. Klien mempunyai kakek dan nenek yang masih hidup baik dari ayah maupun ibunya. Hubungan klien dengan kakek dan nenek dari kedua orang tuanya terjalin baik, tetapi klien merasa lebih dekat dengan kakek dan nenek dari ayahnya. Setelah kedua orang tua klien bercerai, klien tinggal bersama kakek dan nenek dari ayahnya di Indramayu, sedangkan ibunya pergi ke J akarta.

Klien bercerita sebenarnya hubungan klien dengan kedua orang tuanya dekat dan terjalin dengan baik, walaupun dulu sebelum kedua orang tuanyabercerai, mereka seringbertengkar.Tetapi setelah orang tuanya bercerai, klien menjadi lebih dekat dengan ayahnya. Klien sangat ingin membuat orang tuanya bangga dan klien pun tidak ingin menyulitkan orang tuanya, maka dari itu ia sejak umur 12 tahun klien sudah mulai berusaha mencari uang sendiri.

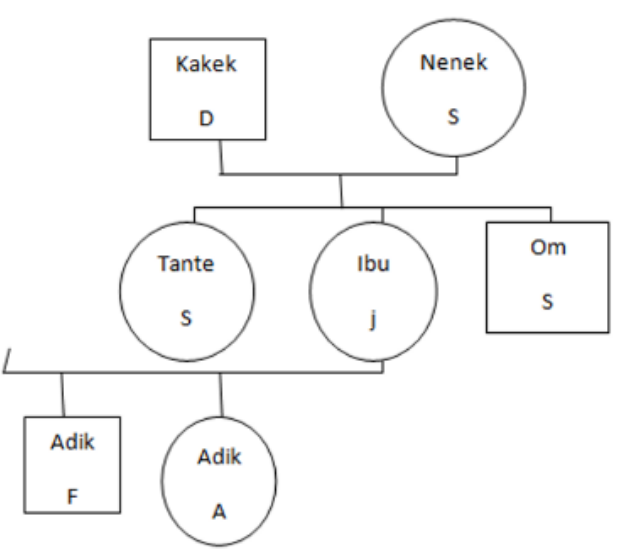

Klien lakukan untuk mencari uang adalah dengan ngamen, ia pernah mencoba untuk menunggu makanan dan kerja di konveksi tetapi itu tidak berlangsung lama karena faktor penghasilan yang tidak jelas. Lalu klien pun diajak oleh temannya mengamen dan akhirnya sampai tahun 2017 ia pun bekerja di jalanan (ngamen).

Hubungan klien dengan adik-adiknya terbilang dekat dan baik-baik saja, tetapi sejak klien pergi dari rumah untuk bekerja,klien pun mengaku semakin jarang bertemu dengan adikadiknya. Setelah orang tuanya bercerai, adikadiknya ikut dengan ibunya ke Jakarta.

Sejak bekerja (ngamen), klien sangat dekat dengan teman-temannya, karena temannyalah yang mengajak klien mengamen untuk mendapatkan uang. Klien merupakan tipe orang yang susah untuk mengatakan tidak pada ajakan temannya, sehingga klien terbawa oleh pergaulan teman-temannya dan mulai ikut-ikutan menggunakan tato, tindik, minum-minuman keras, dan memakai obat-obatan terlarang. Walaupun klien mengakui bahwa setelah masuk Lembaga Pemasyarakatan Khusus Anak (LPKA)klien menyadari bahwa teman-temannya ada untuk 


\begin{tabular}{|c|c|c|c|c|}
\hline $\begin{array}{c}\text { Focus: } \\
\text { Jurnal Pekerjaan Sosial }\end{array}$ & ISSN: 2620-3367 & Vol. 2 No: 1 & Hal: $67-83$ & Juli 2019 \\
\hline
\end{tabular}

dirinya hanya pada saat klien sedang senang saja, karena pada saat klien terpuruk teman-temannya tidak selalu ada di sisinya. Klien mengungkapkan bahwa teman-temannya pernah mengunjunginya sekali selama klien tinggal di LPKA.

Hubungan klien dengan teman-temannya
Klien juga menyebutkan bahwa teman dekatnya di LPKA berasal dari Indramayu yaitu $R$.

Berdasarkan berbagai penjelasan klien terkait hubungannya dengan keluarga dan lingkungan sosialnya, hal tersebut tertuang dalam diagram ecomap berikut ini :

Diagram 2

Ecomap Klien

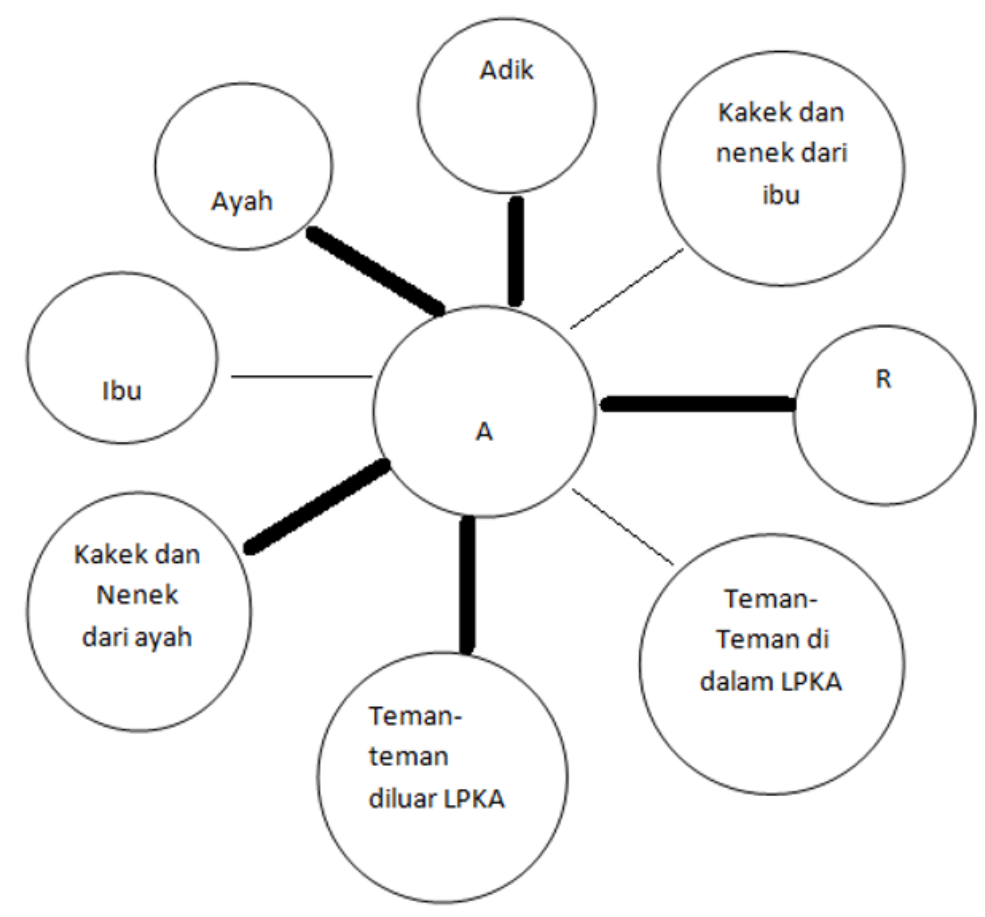

Sumber: Praktikum Pekerjaan Sosial dengan Individu dan Pengembangan Diri, 2019

di LPKA terjalin baik. Klien mengungkapkan bahwa tidak ada teman yang membuatnya begitu terganggu karena di LPKA semuanya temantemannya sedang merasakan penderitaan yang sama dengan klien. Klien merasa cukup dekat dengan teman-temannya yang masuk LPKA bersamaan. Klien memang bukan tipikal orang yang mudah bergaul, tetapi ia masih berusaha untuk selalu menyapa teman-temannyawalaupun klien merasa tidak terlalu dekat dengan mereka.
Setelah praktikan melakukan assessment, praktikan mendapatkan informasi/databahwa bahwa klien sejak dulu adalah orang yang tidak percaya diri dan bukanlah orang yang mudah untuk berkomunikasi dengan orang lain. Terlebih bila klien harus berbicara atau tampil di depan banyak orang. Walaupun sebelumnya ia bekerja di jalanan (ngamen) yang mengharuskannya tampil di depan banyak orang, ternyata saat itu klien dan temantemannya menggunakan obat-obatan terlarang 


\begin{tabular}{|c|c|c|c|c|}
\hline $\begin{array}{c}\text { Focus: } \\
\text { Jurnal Pekerjaan Sosial }\end{array}$ & ISSN: $2620-3367$ & Vol. 2 No: 1 & Hal: $67-83$ & Juli 2019 \\
\hline
\end{tabular}

atau meminum minuman keras agar mereka bisa tempil percaya diri di depan orang banyak. Klien beranggapan bahwa semua orang yang tidak kenal dengannya pasti akan melihat dirinya adalah orang yang aneh terutama dengan penampilannya yang bertato dan memakai tindik.

Klien juga mengaku bahwa selama ini ia bertato, minum-minuman keras dan memakai obat-obatan adalah ajakan dari teman-temannya. Semua yang ia lakukan hanya mengikuti teman-temannya karena saat praktikkan bertanya apakah tato tersebut memiliki arti bagi klien ia tidak bisa menjawabnya tetapi hanya menjawab semua mengikuti teman-temannya. Praktikkan juga menanyakan apakah klien tidak bisa menolaknya jika memang klien kurang berkenan tetapi klien menjawab bahwa ia tidak enak untuk menolak teman-temannya itu. Maka dari itu praktikan memutuskan agar klien mengikuti Assertivnes training bersama teman-teman lainnya.

Dan praktikkan melihat saat AssertivenesTraining klien saat bersama kelompoknya mendiskusikan respon dan berbagi peran klien tidak mau menjadi orang yang banyak berbicara ia hanya mau menjadi pelengkap di adegan tersebut walaupun fasilitator sudah mendorong agar ia berbicara tetapi ia tetep tidak mau. Dan setelah training selesai praktikkan kembali berbicara secara individu dengan klien dan saya bertanya mengapa tadi hanya terlihat diam saja, ia pun menjawab bahwa ia malu untuk berbicara dan ia merupakan pribadi yang nonassertive, jadi dia akan mengikuti saja apapun yang temannya katakan.

\section{Plan of Treatment (POT)}

Hasil Assessmen tterhadap klien menunjukkan bahwa klien menghadapi beberapa permasalahan yaitu:

1) Klien tidak percaya diri untuk berbicara ataupun tampil di hadapan orang banyak, karena klien takut kalo orang lain yang melihat dirinya akan menganggap klien sebagai orang yang aneh karena penampilannya.

2) Klien tidak bisa menolak jika diajakan melakukan sesuatu oleh temannya.

3) Bingung bagaimana cara berkomunikasi dengan orang yang baru ia kenal

4) Kurang berpikir positif terkait berbagai kejadian yang telah klien alami.

Dengan demikian, plan of treatment yang dapat dilakukan adalah:

1) Tujuan: Praktikan mengarahkan klien agar memiliki pikiran alternatif yang positif, sehingga saat klien mengalami suatu kejadian yang tidak menyenangkan, klien tidak langsung bertindak secara semaunya sendiri, melainkan harus berpikir terlebih dahuludengan tenang dan bisa berpikir positif, sehingga tidak menimbulkan emosi yang meledakledak.

2) Praktikan memberitahu manfaat dan tujuan dari dibuatnya cognitive restructuring form (CRF)agar klien lebih banyak memikirkan berbagai pikiran otomatis yang positif dan mengubah segala pikiran negatifnya. Selain itu, praktikanjuga memberitahu 


\begin{tabular}{|c|c|c|c|c|}
\hline $\begin{array}{c}\text { Focus: } \\
\text { Jurnal Pekerjaan Sosial }\end{array}$ & ISSN: $2620-3367$ & Vol. 2 No: 1 & Hal: $67-83$ & Juli 2019 \\
\hline
\end{tabular}

manfaat dan tujuan dilakukannya teknik deep breathing. Teknik deep breathing yang digunakan oleh praktikan adalah teknik gelembung soda, sebenarnya teknik ini sama dengan teknik deep breathing lainnya.Namun, dalam teknik gelembung soda, klien harus membayangkan suara yang mengganggu seperti gelembung soda yang hilang dipermukaan.Teknik deep breathingsangat penting untuk dilakukan pada saat klien merasakan emosi, khawatir, cemas ataupun gugup. Teknik deep breathing ini ditujukan agar klien bisa rileks kembali dan klien pun diharapkan untuk selalu berpikian positif dan tenang dengan segala situasi dan kondisi yang dihadapinya.

3) Praktikan memberi waktu kepada klien selama dua mingguuntuk proses pengisian cognitive restructuring form (CRF)dan secara rutin praktikan melakukan pendampingan dan eveluasi.

\section{Treatment}

Berdasarkan hasil assessment dan plan of treatment, maka intervensi yang akan dilakukan olehpraktikan terhadap klien adalah mengenai peningkatan kepercayaan diri klien melalui teknik rational therapy dengan menggunakan cognitive restructuring form (CRF) 6 kolom, seperti yang tertuang dalam tabel 3 berikut ini:

Tabel 3

Kondisi Klien Dalam Cognitive Restructuring Form (CRF) 6

\begin{tabular}{|c|c|c|c|c|c|}
\hline $\begin{array}{l}\text { Treatment } \\
\text { hari ke- }\end{array}$ & $\begin{array}{c}\text { Pengalaman } \\
\text { Emosi }\end{array}$ & $\begin{array}{c}\text { Presentase } \\
(\%)\end{array}$ & $\begin{array}{c}\text { Pikiran-pikiran } \\
\text { otomatis/Self } \\
\text { Talk Negative } \\
\text { yang } \\
\text { menyebabkan } \\
\text { emosi }\end{array}$ & $\begin{array}{c}\text { Tanggapan } \\
\text { rasional } \\
\text { terhadap } \\
\text { pemikiran } \\
\text { otomatis/ Self } \\
\text { Talk Positif }\end{array}$ & $\begin{array}{c}\text { Presentase } \\
(\%)\end{array}$ \\
\hline 1 & $\begin{array}{c}\text { Memanggil } \\
\text { orang pas } \\
\text { dilihat ternyata } \\
\text { salah orang }\end{array}$ & $95 \%$ & $\begin{array}{c}\text { Dia pasti } \\
\text { berpikir aku } \\
\text { kurang } \\
\text { konsentrasi }\end{array}$ & $\begin{array}{c}\text { Dia juga pasti } \\
\text { ngerti }\end{array}$ & $50 \%$ \\
\hline 2 & $\begin{array}{l}\text { Buang kulit } \\
\text { pisang } \\
\text { sembarangan eh } \\
\text { malah kena } \\
\text { orang }\end{array}$ & $70 \%$ & $\begin{array}{l}\text { Dia pasti marah } \\
\text { banget sama aku }\end{array}$ & $\begin{array}{c}\text { Dia pasti cuma } \\
\text { marah sesaat }\end{array}$ & $35 \%$ \\
\hline 3 & $\begin{array}{l}\text { Nyuci baju } \\
\text { orang pas di } \\
\text { jemur dan di } \\
\text { angkat baju } \\
\text { orangnya ilang }\end{array}$ & $100 \%$ & $\begin{array}{c}\text { Dia pasti kesel } \\
\text { sama aku }\end{array}$ & $\begin{array}{c}\text { Dia pasti } \\
\text { kecewa sama } \\
\text { aku }\end{array}$ & $80 \%$ \\
\hline 4 & $\begin{array}{l}\text { Lagi bawa takjl } \\
\text { di mangkok } \\
\text { terus mangkok } \\
\text { nya jatoh sama } \\
\text { orang lain }\end{array}$ & $80 \%$ & $\begin{array}{l}\text { Dia salah tapi } \\
\text { gamau minta } \\
\text { maaf }\end{array}$ & $\begin{array}{c}\text { Dia pasti } \\
\text { gapunya otak }\end{array}$ & $75 \%$ \\
\hline
\end{tabular}

Sumber: Praktikum Pekerjaan Sosial dengan Individu dan Pengembangan Diri, 2019 


\begin{tabular}{|c|c|c|c|c|}
\hline $\begin{array}{c}\text { Focus: } \\
\text { Jurnal Pekerjaan Sosial }\end{array}$ & ISSN: 2620-3367 & Vol. 2 No: 1 & Hal: $67-83$ & Juli 2019 \\
\hline
\end{tabular}

Dari tulisan yang di beri warna biru terlihat bahwa self talk positif klien masih terdapat sedikit kejanggalan dan harus di luruskan karena dari no 3, klien menuliskan "Dia pasti kecewa sama aku" karena kata-kata tersebut masih termasuk dalam self talk negatif dan tidak akan membuat pikiran klien tenang. Sedangkan dari no 4, klien menuliskan "dia pasti gapunya otak" kata-kata tersebut mungkin saja bisa menenangkan pikiran dan emosi klien tetapi bukan kata-kata sepeti itu yang seharusnya menjadi self talk positif.

Klien masih bingung mengenai self-talk positive apa yang harus dimunculkan. Klien masih harus dibimbing untuk mengontrol tabel $C R F$ ini. Dari waktu dua minggu yang diberikan kepada klien untuk mengisi $C R F$ ini, klien hanya bisa mengisi 4 poin. Hal ini dikarenakan klien masih merasa bingung mengenai kejadian apa yang harus dituliskan dalam tabel $C R F$ dan karena tidak begitu banyak kejadian yang menimbulkan emosi bagi klien saat tinggal di dalam LPKA.

Dalam proses pengisian tabel $C R F$, di minggu pertama klien baru mengisi hingga kolom kedua dan ketika dilakukan pengecekan oleh praktikan, apa yang dikerjakan oleh klien sudah benar dalam menentukan pikiran positif yang muncul. Lalu di minggu kedua, praktikan mengecek kembali tabel CRF tersebut dan ada beberapa pengisian yang kurang tepat, tetapi praktikan langsung melakukan evaluasi dan meluruskan apa yang seharusnya dilakukan oleh klien.

Selain membuat tabel CRF, teknik deep breathingpun digunakan praktikan untuk mengintervensi klien sesuai dengan rencana intervensi yang telah dibuat. Intervensi ini dilakukan agar klien dapat rileks dan nyaman saat berada dalam situasi atau kondisi yang kurang nyaman bagi dirinya, sehingga klien tidak merasakan emosi negatif ataupun merasa tidak tenang dan kehilangan kendali. Teknik deep breathing yang digunakan oleh praktikan adalah teknik gelembung soda,yaitu klien harus membayangkan suara yang mengganggu seperti gelembung soda yang hilang dipermukaan. Setelah melakukkan beberapa kali teknik ini klien mengungkapkan bahwa dirinya merasa lebih tenang dan lega.

\section{Terminasi}

Setelah melalui tahapan intervensi dan evaluasi, maka tahapan selanjutnya adalah terminasi. Terminasi adalah salah satu tahap dimana praktikan harus mengakhiri proses praktikum dan minimal target dari intervensi telah tercapai.Target minimal yang praktikan targetkan dalam intervensi ini adalah klien dapat berpikir positif tentang apapun yang membuatnya merasa terganggu agar bisa lebih percaya diri untuk berinteraksi dengan banyak orang.

Terminasi dilakukan dan praktikan menjabarkan apa saja yang telah klien capai selama dari awal proses assessment dan treatment. Klien menyatakan bahwa teknik pengisian tabel CRFsangat berguna bagi klien, yaitu agar ia tidak memandang dirinya rendah dan setelah di lakukan evaluasi yang terakhir kalinya oleh praktikan, di dapatkan hasil bahwa klien semakin mengerti dan dapat menyatakan pikiran positif dengan baik. Begitu pun dengan teknik deep breathing yang sudah dilakukan, klien menyatakan suka menggunakan teknik deep breathing pada saat ia merasa tidak tenang dan terganggu. 


\begin{tabular}{|c|c|c|c|c|}
\hline $\begin{array}{c}\text { Focus: } \\
\text { Jurnal Pekerjaan Sosial }\end{array}$ & ISSN: 2620-3367 & Vol. 2 No: 1 & Hal: $67-83$ & Juli 2019 \\
\hline
\end{tabular}

\section{Evaluasi}

Setelah berbagai treatment dilakukan bersama klien, maka proses evaluasi dilakukan untuk menilai apakah proses pendampingan berjalan sesuai dengan rencana atau tidak. Berikut ini adalah hal-hal yang diperoleh dalam proses eveluasi, yaitu:

1) Saat proses pendampingan, klien mengungkapkan bahwa ia merasa senang dapat terlibat dalam kegiatan praktikum yang dilakukan oleh praktikan dan klien merasa mendapatkan banyak hal berharga, tidak hanya dari proses pengisian tabel CRF dan melakukan teknik deep breathing saja, melainkan juga karena praktikan sering memberi berbagai macam masukkan yang dirasa oleh klien berharga, misalkan pada saat klien diberi masukan bahwa berkomunikasi, pendidikan dan menolak secara halus banyak memberi manfaat walaupun sebenarnya sulit untuk dilakukan. Klien selalu antusias dan mengerti terhadap hal-hal yang disampaikan oleh praktikan, sehingga klien mengatakan bahwa kegiatan praktikum ini sangat bermanfaat bagi diri klien.

2) Klien mengatakan bahwa dalam menjalani proses pendampingan ia dapat lebih terbuka dan berani jujur. Padahal biasanya klien tidak bisa terbuka dengan orang yang baru ia kenal. Walaupun di pertemuan awal klien masih tidak banyak bicara tetapi pada pertemuan kedua dan pertemuan-pertemuan berikutnya klien sudah bisa banyak bertanya dan bercerita mengenai kegiatan kesehariannya di LPKA.

3) Setelah dibimbing untuk mengisi tabel $C R F$, klien dapat memahami bahwa dirinya sedang berada di dalam kondisi yang tidak nyaman dan memiliki rasa malu yang besar dalam dirinya. Kemudian klien dapat memunculkan pikiran-pikiran positifnya, sehingga rasa malu dan rasa tidak percaya diri klien dapat menurun.

4) Klien mengungkapkan bahwa saat sedang malu atau tidak percaya diri klien harus tenang dan tidak boleh merasa panik karena hal itu akan memicu rasa tidak percaya diri yang berlebihan. Teknik deep breathinggelembung soda digunakan untuk membantu klien agar dapat lebih tenang dan rileks dalam menghadapi situasi yang dirasakannya tidak nyaman.

5) Tujuan intervensi telah tercapai, klien sudah dapat mengeluarkan pikiranpikiran positif. Namun, klien perlu berlatih lebih banyak untuk dapat berbicara dan tampil di depan banyak orang.

6) Kesulitan berkomunikasi antara praktikandengan klien di luar sesi pertemuan, yaitu untuk menanyakan hal-hal yang terlewat saat melakukan proses pendampingan. $\mathrm{Hal}$ ini dikarenakan klien berada di dalam 


\begin{tabular}{|c|c|c|c|c|}
\hline $\begin{array}{c}\text { Focus: } \\
\text { Jurnal Pekerjaan Sosial }\end{array}$ & ISSN: 2620-3367 & Vol. 2 No: 1 & Hal: $67-83$ & Juli 2019 \\
\hline
\end{tabular}

LPKA dan dilarang untuk menggunakan handphone.

\section{Simpulan dan Saran}

Simpulan yang diperoleh dengan dilakukannya kegiatan praktikum ini adalah bahwa:

1. Klien sudah memiliki pikiran positif yang cukup baik, tetapi masih harus didampingi agar lebih baik lagi.

2. Klien bisa lebih tenang saat menghadapi kondisi yang membuatnya tidak nyaman.

Adapun saran yang dapat disampaikan oleh praktikan terhadap klien adalah:

1. Klien diharapkan terus berlatih teknik deep breathing dan selalu berlatih untuk menggunakan Self-Talk Positifagar saat berada dalam kondisi yang membuat klien merasa tidak nyaman, klien dapat secara otomatis menggunakan teknik tersebut.

2. Diharapkan klien dapat lebih tenang saat akan mengambil sebuah keputusan.

\section{Daftar Pustaka}

Alfin Miftahul Khairi, G. F. (2017). Cognitive Rerstructing Sebagai Upaya Preventif Bunuh Diri Siswa Di Sekolah. Jurnal IImiah Dalam Implementasi Kurikulum Bimbingan Dan Konseling , 10-19.

Bandura, A. 1997. Self Efficacy -The Exercise of Control(Fifth Printing, 2002). New York: W.H. Freeman \& Company.

Bunker,B.B., Major,B., \& Instone,D., 1983, Gender, Self Confidence, and Influence Strategies: An Organizational Simulation, Journal of Personality and Social Psychology, Volume 44, No 2,322-333, USA: APA Inc.

Edward Smith, Daryl J. Bem. 1953. Introduction to Psychology : Pengantar Psikologi. (11th ed.). Jilid 1, versi Bahasa Indonesia. Batam: Interaksara.

Debrun, (1990). Psikologi untuk anak, remaja dan dewasa. Episentrum. Tersedia di: http://episentrum.com/search/Debrun(dal am rice 1990)

Dilla Tria Febrina, P. L. (2018). Self Esteem Remaja Awal. Jurnal Psikologi Insight , 43-56.

Dyana C. Jatnika, S. T. (2016). Pekerjaan Sosial Koreksional. Sumedang: Unpad Press.

Emria Fitri, N. Z. (2018). Profil Kepercayaan Diri Remaja serta Faktor-Faktor yang Mempengaruhi. Jurnal Penelitian Pendidikan Indonesia , 1-5.

Hurlock, E.B. 1991. Psikolgi Perkembangan Suatu Pendekatan Sepanjang Rentang Kehidupan. J akarta : Penerbit Erlangga.

Hurlock, E. B. 1981. Perkembangan Anak. Jilid I. edisi ke-6: Erlangga

Jahja, Yudrik. 2012. Psikologi Perkembangan. J akarta: Kencana

Khamim Zarkasih Putro. (2017). Memahami Ciri dan Tugas Perkembangan Masa Remaja. J urnal Aplikasi IImu-ilmu Agama , 25-32.

Lauster, P. 1978. The Personality Test (2nd.Ed). London: Bantam Books, Ltd.

Malahayati. (2010). Super teens. Yogyakarta: J ogjaBangkitPu-blisher.

Mastuti \& Aswi. 2008. 50 Kiat percaya diri. Jakarta : PT. Buku Kita 


\begin{tabular}{|c|c|c|c|c|}
\hline $\begin{array}{c}\text { Focus: } \\
\text { Jurnal Pekerjaan Sosial }\end{array}$ & ISSN: 2620-3367 & Vol. 2 No: 1 & Hal: $67-83$ & Juli 2019 \\
\hline
\end{tabular}

Pane, R. M. (t.thn.). Terminasi Hubungan Konseling. 107-117.

Papalia, D. E., Old, S. W., Feldman, \& R.D. (2001). Perkembangan Manusia. Jakarta: Salemba Humanika

Reyaan, M. N. (2015). Hubungan Antara Kepercayaan Diri Dengan Perilaku menyontek Pada Mahasiswa UST. Jurnal SPIRITS , 18-22.

Rizkiyah. (2005). Hubungan Antara Penerimaan Kelompok Teman Sebaya Dengan Kepercayaan Diri Remaja Awal Siswa Kelas XI IPS SMAN 5 Bekasi.Skripsitidak dipublikasikan. Fakultas Keguruan dan IImu Pendidikan, Universitas Islam AsSyafi'iyah, Jakarta.

Santrock, Adolescence, J akarta: Erlangga, 2003

Siska, S. E. (2003). Kepecayaan Diri Dan Kecemasan Komunikasi Interpersonal Pada Mahasiswa. J urnal Psikologi, 67 - 71.

Siti Meichati, S. S. (1976). Tanggapan Remaja Mengenai Diri Dan Kehidupannya. Jurnal Psikologi, 58-74.

Sundari, W. (2008). Analisis Struktur Pada Gendre Aabstrak Artikel Berbahasa Inggris. 45-53. Syam, A. (2017). Pengaruh Kepercayaan Diri (Self Confidence) Berbasis Kaderisasi IMM Terhadap Prestasi Belajar Mahasiswa. J urnal Biotek , 87-99.

Willis, Sofyan S, 1985, Problema Remaja dan Pemecahannya, Jakarta : Bulan Bintang

Pasal 1 ayat (2) Undang-Undang Nomor 11 tahun 2012 (t.thn.). Dipetik junii 8, 2019, dari peduli wni kemenlu: https://peduli wani. kemenlu.go.id

Undang-Undang No.12 Tahun 1995(t.thn.). Dipetik junii 8, 2019, dari peduli wni kemenlu: https://peduli wani. kemenlu.go.id

Undang-Undang No. 11 Tahun 2012(t.thn.). Dipetik junii 8, 2019, dari peduli wni kemenlu: https://peduliwani. kemenlu.go.id 